\title{
Heavy metal enrichment in the riparian sediments and soils of the Three Gorges Reservoir, China
}

\author{
QIANG TANG ${ }^{1,2}$, YUHAI BAO ${ }^{1}$, XIUBIN HE $^{\mathbf{1}}$ \& ANBANG WEN ${ }^{1}$ \\ 1 Key Laboratory of Mountain Surface Processes and Ecological Regulation, Institute of Mountain Hazards and \\ Environment, Chinese Academy of Sciences, Chengdu 610041, China \\ xiubinh@imde.ac.cn \\ 2 State Key Laboratory of Urban and Regional Ecology, Research Center for Eco-Environmental Sciences, Chinese \\ Academy of Sciences, Beijing 100085, China
}

\begin{abstract}
The Three Gorges Reservoir encompasses a riparian zone with a vertical height of $30 \mathrm{~m}$ and a total area of $349 \mathrm{~km}^{2}$ that has been subjected to alternate inundation and exposure due to regular impoundment. Sedimentation on the riparian landforms constitutes an important pathway for riverine contaminant redistribution. In an attempt to understand heavy metal enrichment since water inundation, riparian sediments and soils were sampled along five transects in a typical riparian zone composed of cultivated bench terraces in the middle reaches. Heavy metals $(\mathrm{Cr}, \mathrm{Ni}, \mathrm{Cu}, \mathrm{Zn}, \mathrm{As}, \mathrm{Cd}$ and $\mathrm{Pb}$ ) were determined to characterize the lateral distribution and vertical transfer ratio. The results indicated that all heavy metals were enriched to varying extents both in the riparian sediments and soils, compared with regional background contents in soils and the reference levels in sediments. However, heavy metal levels in the riparian sediments were generally higher than those in the riparian soils, while those in the upper riparian soils $(0-5 \mathrm{~cm})$ were overall slightly higher than those in the lower riparian soils $(5-10 \mathrm{~cm})$. There was a decreasing trend of heavy metal contents with increasing elevation. The elevated levels of heavy metals in the riparian sediments may be attributed to sediment yields from upstream anthropogenic sources, especially during major rainstorms in the wet season when large loads of contaminated sediment may be produced from diffuse source areas. Heavy metals can also be adsorbed to pure sediment in the course of mobilization or after deposition. Considering that the riparian soils are local weathering products without mobilization, the enrichment of heavy metals may principally be ascribed to chemical adsorption from dissolved fractions or vertical transfer from overlaid sediments. Heavy metal enrichment may further be affected by the specific type of hydrologic regime such that relatively long flooding duration caused by water impoundment and natural floods was responsible for the relatively higher levels of heavy metals in the lower portions of the riparian zone.
\end{abstract}

Key words sedimentation; heavy metal; diffuse contaminants; riparian zone; Three Gorges Reservoir

\section{INTRODUCTION}

The Three Gorges Dam intercepts the main course of the Yangtze River at the outlet of its upper basin and comprises a mountainous and hilly drainage basin of approximately 1 million $\mathrm{km}^{2}$ (Fig. 1). The Three Gorges Reservoir was primarily impounded when the water level rose to $135 \mathrm{~m}$ in 2003. Since then, the water level increased further to $156 \mathrm{~m}$ in 2006 and $172 \mathrm{~m}$ in 2008. Full operation of the reservoir was implemented in 2009 when the water level rose to $172.4 \mathrm{~m}$. Regular operation of the Three Gorges Reservoir with a strategy of "impounding clean water and draining turbid water" has caused inundation to the maximum level of $175 \mathrm{~m}$ during the dry season (October-April) for hydropower generation followed by a drop to $145 \mathrm{~m}$ during the wet season (May-September) for flood control (Zhang and Luo, 2011). Water level fluctuations between 145 and $175 \mathrm{~m}$ has formed a riparian zone with a vertical height of $30 \mathrm{~m}$ and a total land area of $349 \mathrm{~km}^{2}$ stretching $660 \mathrm{~km}$ from Yichang to Chongqing (Fig. 1). The riparian zone was transformed from the previous hillslopes with arable land, bench terraces, rural residential, urban area, wasteland, grassland and woodland to a unique aquatic-terrestrial landscape subjected to alternate flooding and exposure.

The change of hydrologic regime due to the regular reservoir impoundment has caused many environmental challenges regarding the riparian zone (Fu et al., 2010; Li et al., 2013; Xu et al., 2013), among which significant sedimentation has taken place due to high suspended sediment yields from upstream basins and local tributary catchments, bank erosion in the riparian landscape and declining flow velocity within the dammed reaches (Tang et al., 2014; Fig. 2). Large quantities of sediment deposited in the riparian zone serve as an important sink of riverine contaminants (i.e. nutrients, heavy metals, organic materials, etc.), which may lead to complex 


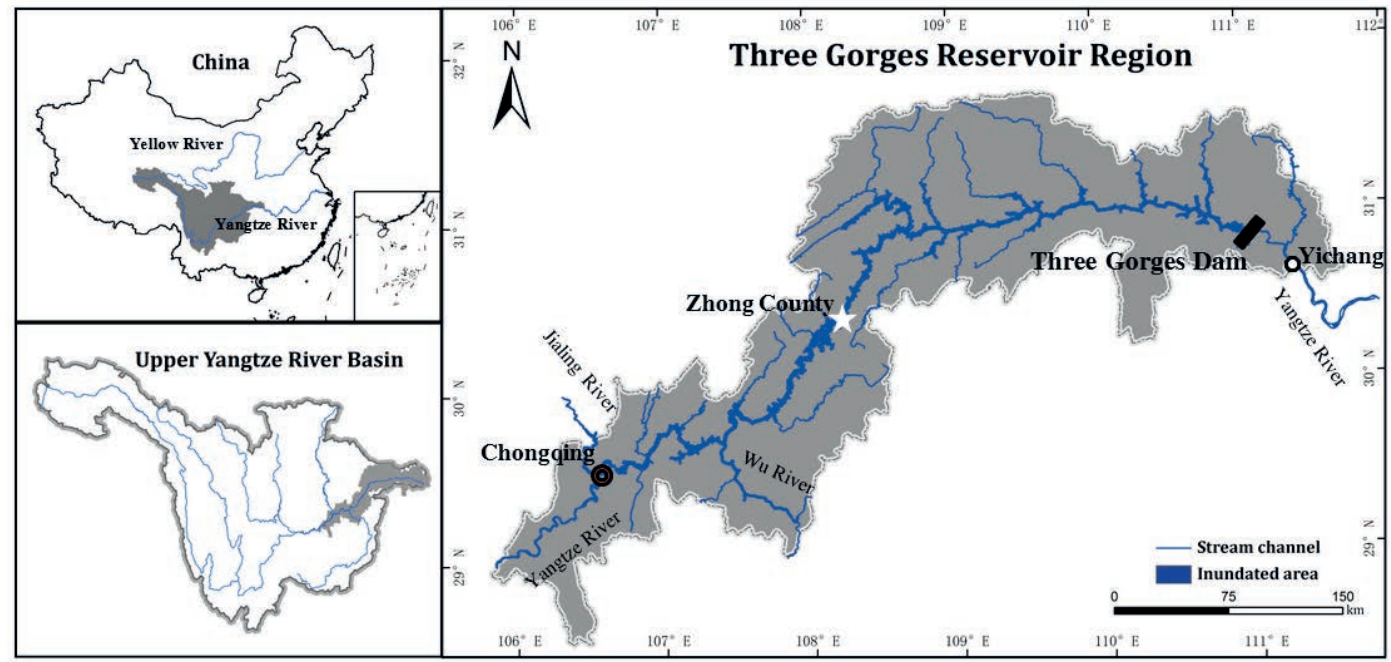

Fig. 1 Geographical map of the Three Gorges Reservoir and location of the study area.

environmental consequences for the riparian ecosystem and aquatic environment. Although there have been a number of studies dealing with heavy metal contamination in the riparian zone at the regional scale (e.g. Lin et al., 2012; Ye et al., 2012, 2013), detailed lateral and vertical enrichment patterns of heavy metals in the riparian zone and the effect of the altered hydrologic regime have been rarely studied and are not well understood. Furthermore, heavy metal enrichment in the riparian sediments and soils was conducted through different processes due to the differences in origins and transport pathways. The present study attempts to conduct a comparative assessment of heavy metal enrichment in the riparian sediments and soils.

\section{MATERIALS AND METHODS}

\section{Study area}

A typical riparian zone composed of cultivated bench terraces in the middle Three Gorges Reservoir (Zhong County of Chongqing Municipality, geographically at $30^{\circ} 26^{\prime} \mathrm{N}, 108^{\circ} 11^{\prime} \mathrm{E}$ ) was selected for this study (Fig. 1). The region is characterized by a humid subtropical monsoon climate. The mean annual temperature and precipitation are $18.2^{\circ} \mathrm{C}$ and $1172 \mathrm{~mm}$, respectively, and much of the annual precipitation occurs in the wet season from May to September (Wang et al., 2012). The bed rocks of the study area include sandstones, siltstones and mudstones of the Jurassic Shaximiao Group (J2s), mixed with widely distributed "purple soil", an early weathering product of Jurassic rocks. The purple soil contains $18 \%$ clay, $30 \%$ silt and $52 \%$ sand and is classified as an Orthic Entisol in the Chinese Soil Taxonomic System, a Regosol in the FAO Taxonomy, or an Entisol in the USDA Taxonomy (He et al., 2009). The average soil $\mathrm{pH}$ is $6.2 \pm$ 0.9 (mean value \pm standard error, the same applies to all following values) and the average water content is $20.0 \pm 0.7 \%$ (Ye et al., 2012).

\section{Sampling}

Sediment and soil sampling were conducted along five representative transects in August 2010 when the water level remained almost at the base level and the riparian zone was completely exposed. Along each transect, sampling plots of $1 \times 1 \mathrm{~m}$ grids were selected based on the topographic variation. The boundary between the riparian sediment and soil was identified by comparing the vertical and horizontal changes of colour and texture on soil profiles (Fig. 2). Riparian sediments (with depth less than $10 \mathrm{~cm}$ ) and down-profile sectioned riparian soils (at $5 \mathrm{~cm}$ intervals: upper soils of $0-5 \mathrm{~cm}$ and lower soils of 5-10 $\mathrm{cm}$ ) in individual plots were sampled randomly with a plastic shovel and mixed to form a composite sample. All samples were sealed in polyethylene bags and transported to our laboratory, air-dried at room temperature, manually disaggregated, and sieved through a $2 \mathrm{~mm}$ sieve. 


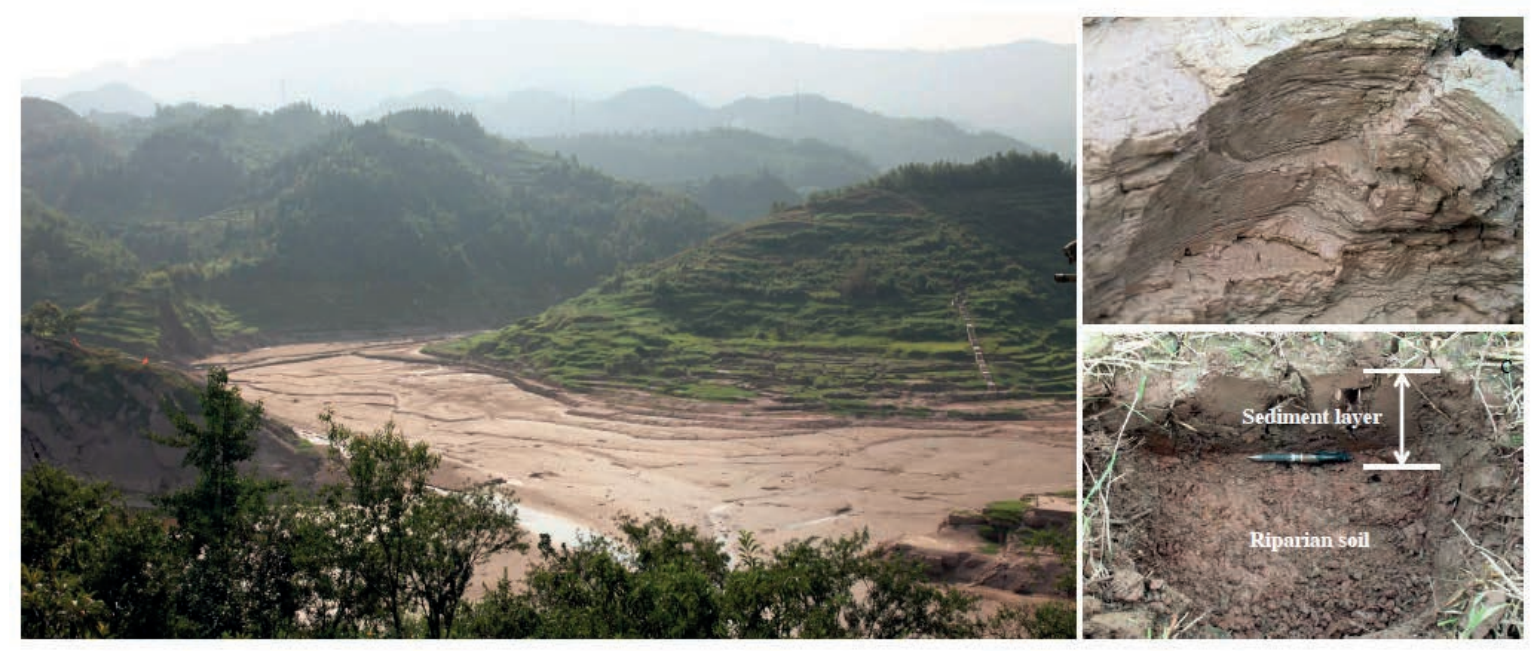

Fig. 2. A typical view of sedimentation in the riparian zone of the TGR and the sediment-soil boundary in field sampling.

\section{Laboratory analysis}

Heavy metals $(\mathrm{Cr}, \mathrm{Ni}, \mathrm{Cu}, \mathrm{Zn}, \mathrm{As}, \mathrm{Cd}$ and $\mathrm{Pb}$ ) contents were determined using flame atomic absorption spectrometry (FAAS) following direct digestion using aqua regia (1 part $\mathrm{HNO}_{3}$ to 3 parts $\mathrm{HCl}$ ) (Allen, 1989). The measurement accuracy was assessed by analysing standard reference materials. All the standard solutions were prepared from analytical grade compounds. For quality control, blank and duplicate samples were analysed in each analysis batch. Replicate samples were made for all extractions and analyses and the average values were used in the calculations. The analytical results based on quality control indicated a satisfactory performance for trace metals and organic matter determinations, with overall uncertainties varying between $5 \%$ and $15 \%$.

\section{RESULTS}

Overall, the riparian sediments have the highest levels of heavy metals, but the values in the upper riparian soils are generally higher than in the lower riparian soils (Table 1). Heavy metal contents in the riparian sediments ranged as follows: $76.4-106(92.76 \pm 1.3) \mathrm{mg} / \mathrm{kg}$ for $\mathrm{Cr}, 41.4-57.6 \mathrm{mg} / \mathrm{kg}$ (49.18 \pm 0.7$)$ for $\mathrm{Ni}, 53.8-102(79.15 \pm 2.0) \mathrm{mg} / \mathrm{kg}$ for $\mathrm{Cu}, 115-189(161.44 \pm 3.4) \mathrm{mg} / \mathrm{kg}$ for $\mathrm{Zn}$, $11.4-20.9(16.59 \pm 0.5) \mathrm{mg} / \mathrm{kg}$ for As, $0.60-1.17(0.89 \pm 0.02) \mathrm{mg} / \mathrm{kg}$ for $\mathrm{Cd}$ and $36.7-81.1$ $(61.27 \pm 1.8) \mathrm{mg} / \mathrm{kg}$ for $\mathrm{Pb}$. All contents are significantly higher than the corresponding regional background levels of soil in the Three Gorges Reservoir Region (Tang et al., 2008) and the reference levels of sediment in the Yangtze River (Song et al., 2010), indicating the enrichment of heavy metals in the riparian sediment since the artificial flooding due to regular reservoir impoundment.

The corresponding contents of heavy metals in the upper riparian soils are: 61.49-96.34 $(75.64 \pm 0.71) \mathrm{mg} / \mathrm{kg}$ for $\mathrm{Cr}, 29.36-50.30(40.14 \pm 0.50) \mathrm{mg} / \mathrm{kg}$ for Ni, 25.94-81.87 (33.42 \pm 0.96$)$ $\mathrm{mg} / \mathrm{kg}$ for $\mathrm{Cu}, 62.91-160.7(91.20 \pm 1.71) \mathrm{mg} / \mathrm{kg}$ for $\mathrm{Zn}, 7.85-17.58(11.40 \pm 0.15) \mathrm{mg} / \mathrm{kg}$ for As, $0.37-1.21(0.50 \pm 0.14) \mathrm{mg} / \mathrm{kg}$ for $\mathrm{Cd}$, and $19.65-67.77(26.46 \pm 0.71) \mathrm{mg} / \mathrm{kg}$ for $\mathrm{Pb}$, respectively. While the contents of the lower riparian soils fell into the range of 64.89-88.67 (74.62 \pm 0.59$)$ $\mathrm{mg} / \mathrm{kg}$ for $\mathrm{Cr}, 31.57-50.62 \mathrm{mg} / \mathrm{kg}(39.68 \pm 0.47)$ for $\mathrm{Ni}, 25.79-48.93(30.44 \pm 0.42) \mathrm{mg} / \mathrm{kg}$ for $\mathrm{Cu}$, $64.74-117.39(87.81 \pm 1.11) \mathrm{mg} / \mathrm{kg}$ for $\mathrm{Zn}, 9.16-13.60(11.36 \pm 0.11) \mathrm{mg} / \mathrm{kg}$ for As, $0.36-0.64$ $(0.46 \pm 0.01) \mathrm{mg} / \mathrm{kg}$ for $\mathrm{Cd}$ and $20.25-88.91(25.95 \pm 1.0) \mathrm{mg} / \mathrm{kg}$ for $\mathrm{Pb}$. All these values are generally higher than regional background contents in soils, suggesting the accumulation of heavy metals during the initial impoundment period of the reservoir.

The contents of heavy metals in the riparian sediments, upper riparian soils and lower riparian soils generally follow a trend of decrease with increasing elevation in the studied riparian zone (Fig. 3). The levels in the riparian sediments collected at the upper portions of the riparian zone approach those of the riparian soils. 
Table 1 Heavy metal contents $(\mathrm{mg} / \mathrm{kg})$ in the riparian sediments, upper riparian soils $(0-5 \mathrm{~cm})$ and lower riparian soils $(5-10 \mathrm{~cm})$.

\begin{tabular}{|c|c|c|c|c|c|c|c|}
\hline Level & $\mathrm{Cr}$ & $\mathrm{Ni}$ & $\mathrm{Cu}$ & $\mathrm{Zn}$ & As & $\mathrm{Cd}$ & $\mathrm{Pb}$ \\
\hline \multicolumn{8}{|c|}{ (A) Riparian sediments } \\
\hline Maximum & 106.41 & 57.61 & 102.60 & 188.67 & 19.98 & 1.04 & 81.07 \\
\hline Median & 94.42 & 49.21 & 79.12 & 165.84 & 16.84 & 0.91 & 62.94 \\
\hline Minimum & 76.84 & 41.38 & 53.78 & 114.71 & 11.44 & 0.60 & 36.71 \\
\hline Mean & $92.76 \pm 1.3$ & $49.18 \pm 0.7$ & $79.15 \pm 2.0$ & $161.44 \pm 3.4$ & $16.59 \pm 0.5$ & $0.89 \pm 0.02$ & $61.27 \pm 1.8$ \\
\hline Extreme ratio & 1.38 & 1.39 & 1.91 & 1.64 & 1.75 & 1.72 & 2.21 \\
\hline Std deviation & 6.69 & 4.02 & 11.06 & 18.56 & 2.44 & 0.11 & 10.10 \\
\hline $\mathrm{Cv}(\%)$ & 7.21 & 8.18 & 13.97 & 11.49 & 14.73 & 12.84 & 16.48 \\
\hline \multicolumn{8}{|c|}{ (B) Upper riparian soils } \\
\hline Maximum & 96.34 & 50.30 & 81.87 & 160.7 & 17.58 & 1.21 & 67.77 \\
\hline Median & 75.18 & 40.38 & 31.11 & 88.90 & 11.29 & 0.47 & 25.12 \\
\hline Minimum & 61.49 & 29.36 & 25.94 & 62.91 & 7.85 & 0.37 & 19.65 \\
\hline Mean & $75.64 \pm 0.71$ & $40.14 \pm 0.50$ & $33.42 \pm 0.96$ & $91.20 \pm 1.71$ & $11.40 \pm 0.15$ & $0.50 \pm 0.14$ & $26.46 \pm 0.71$ \\
\hline Extreme ratio & 1.57 & 1.71 & 3.16 & 2.56 & 2.24 & 3.26 & 3.45 \\
\hline Std deviation & 6.63 & 4.65 & 8.96 & 15.95 & 1.38 & 0.13 & 6.63 \\
\hline $\mathrm{Cv}(\%)$ & 8.76 & 11.57 & 26.82 & 17.49 & 12.08 & 26.02 & 25.06 \\
\hline \multicolumn{8}{|c|}{ (C) Lower riparian soils } \\
\hline Maximum & 88.67 & 50.62 & 48.93 & 117.39 & 13.60 & 0.64 & 88.91 \\
\hline Median & 74.39 & 39.12 & 29.49 & 87.60 & 11.25 & 0.45 & 24.21 \\
\hline Minimum & 64.89 & 31.57 & 25.79 & 64.74 & 9.16 & 0.36 & 20.25 \\
\hline Mean & $74.62 \pm 0.59$ & $39.68 \pm 0.47$ & $30.44 \pm 0.42$ & $87.81 \pm 1.11$ & $11.36 \pm 0.11$ & $0.46 \pm 0.01$ & $25.95 \pm 1.0$ \\
\hline Extreme ratio & 1.37 & 1.60 & 1.90 & 1.81 & 1.48 & 1.80 & 4.39 \\
\hline Std deviation & 5.50 & 4.36 & 3.94 & 10.33 & 0.99 & 0.06 & 9.41 \\
\hline $\mathrm{Cv}(\%)$ & 7.37 & 10.98 & 12.94 & 11.76 & 8.76 & 12.72 & 36.25 \\
\hline $\begin{array}{l}\text { Yangtze } \\
\text { River }^{\mathrm{a}}\end{array}$ & 65.00 & 35.00 & 35.00 & 90.00 & 5.00 & 0.18 & 25.00 \\
\hline $\begin{array}{l}\text { Regional } \\
\text { background }^{\text {b }}\end{array}$ & 78.03 & 29.47 & 25.00 & 69.88 & 5.84 & 0.13 & 23.88 \\
\hline
\end{tabular}

${ }^{a}$ Song et al. (2001)

b Tang et al. (2008)

Std deviation $=$ standard deviation

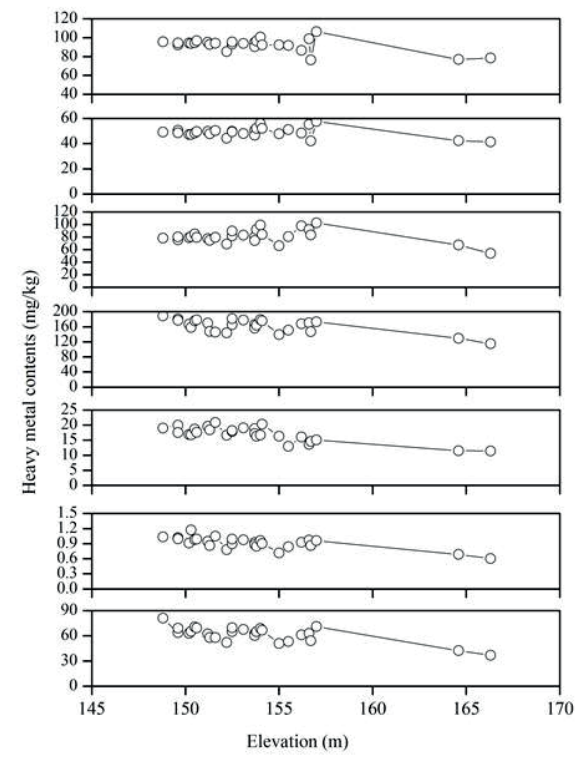

a. Riparian sediments

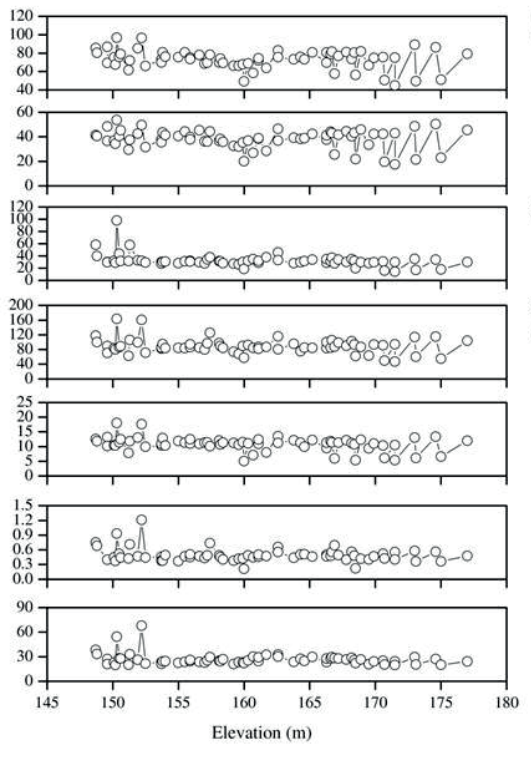

b. Upper riparian soils

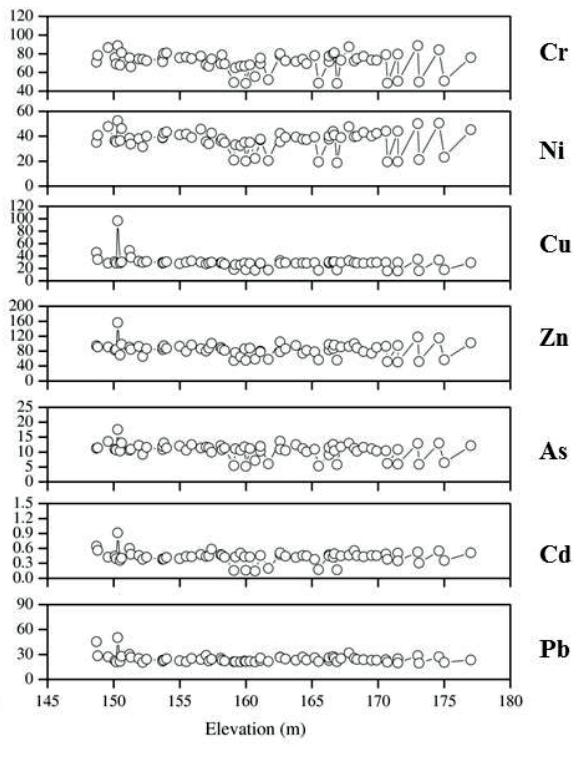

c. Lower riparian soils

Fig. 3 Distribution of the contents of heavy metals in: (a) riparian sediments; (b) upper riparian soils; and (c) lower riparian soils 


\section{DISCUSSION}

Sediments in the riparian zone of the Three Gorges Reservoir originate from suspended sediment yields from upper Yangtze River Basin (i.e. Jinsha, Jialing, Wu and Min), local tributary watersheds, and bank erosion of the riparian zone. However, the contribution of sediment production in the upstream catchments and local watershed may be predominant in sediment in the lower portions of the riparian zone due to substantial fluvial suspended sediment yields in the wet season when relatively low water levels were operated and significant sedimentation mainly occurred within this area. Sediment in the upper portions of the riparian zone may originate from riparian bank erosion triggered by intensive navigation-induced stream waves during the dry season when high water levels were operated.

Enrichment of heavy metals in the riparian sediments was closely related to fluvial hydrology and sediment dynamics. Given the complex processes of sediment yields and redistribution in a large-scale catchment suffered from diverse human disturbances, the excessive contents of heavy metals in the riparian sediments may be partially ascribed to sediment production from upstream anthropogenic sources (e.g. point sources, such as industrial effluents, waste disposal, and diffuse sources, such as road dust, municipal runoffs, and agricultural runoffs). Furthermore, heavy metals can also accumulate during pure sediment mobilization and after deposition in the riparian zone. Accretion of sediments on riparian surfaces has enabled the riparian sediments as a liquid-solid interface and, consequently, heavy metals can be preferentially adsorbed on the riparian sediments rather than down-profile soils.

Considering the immobile nature of the riparian soils (i.e. local weathering products), enrichment of heavy metals in the riparian soils must be attributed to metal adsorption from soluble fractions or vertical transfer of heavy metals from upper riparian sediments. To characterize the vertical transfer of heavy metals along the soil profile, we applied a transfer ratio parameter which was defined as the ratio of levels in the upper riparian soils to that of the lower riparian soils, and the lateral distribution is shown in Fig. 4. The majority of the ratios are larger than 1, emphasizing the vertical differences in the contents of heavy metals in the two soil groups. Furthermore, the ratios observed for riparian soils collected from the lower portions of the riparian zone are obviously larger than those in the upper portions of the riparian zone, indicating the more significant influence of flooding on heavy metal contents in the riparian soils at lower portions of the riparian zone.

The spatial difference in flooding duration may also be responsible for the extent of heavy metal enrichment at different elevations of the riparian zone (Fig. 5). The relatively higher contents of heavy metals in the lower riparian zone may be ascribed to the long inundation duration which favour chemical transfer of heavy metals from the water regime.

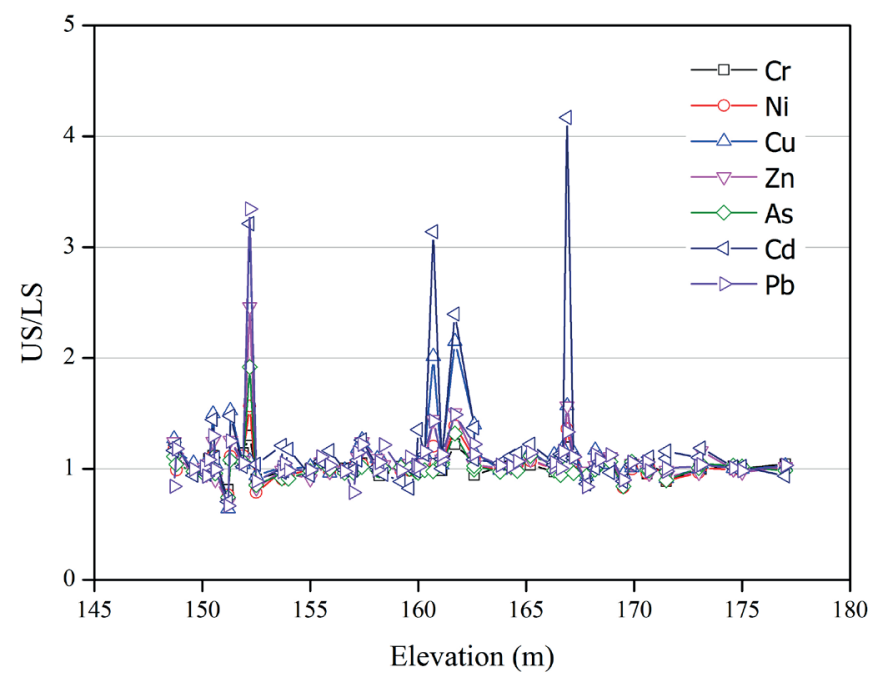

Fig. 4 Lateral distribution of the ratio of levels of heavy metals in the upper soils (US) and lower soils (LS). 


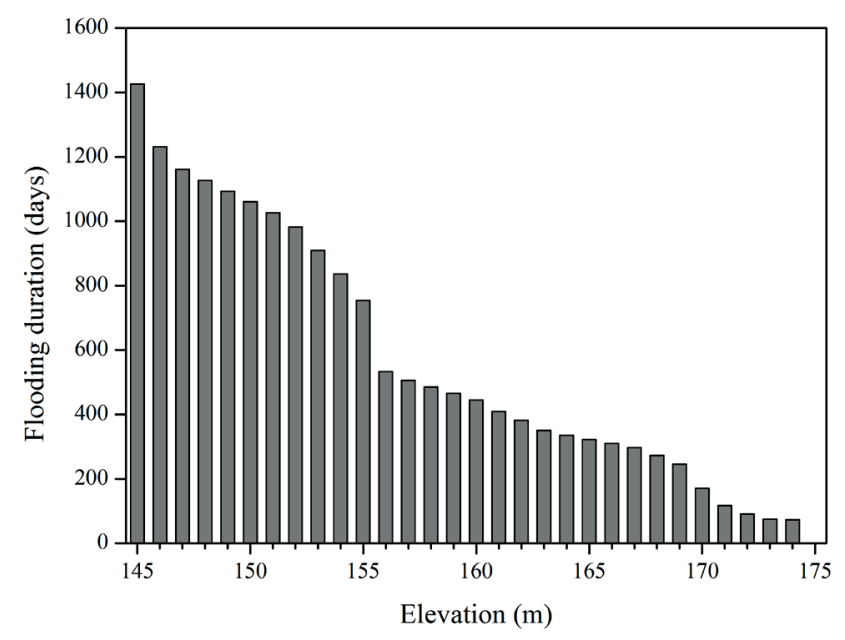

Fig. 5 Inundation duration in relation with elevation in the riparian zone induced by steps of water impoundment and seasonal water level fluctuation.

\section{CONCLUSION}

Seasonal fluctuation of water levels induced by reservoir impoundment and the occurrence of natural floods during the wet season has led to heavy metal enrichment in both the riparian sediments and soils of the Three Gorges Reservoir. A lateral decreasing trend of heavy metal contents in the riparian sediments and soils with the increasing elevation was observed. Heavy metal enrichment in the riparian sediments may be partially attributed to sediment production from upstream anthropogenic sources, especially during major rainstorms in the wet season when large loads of contaminated sediment were produced from diffuse source areas, which consequently contributed to the elevated levels of heavy metals in the lower portions of the riparian zone where significant sedimentation can occur. Additionally, heavy metals can also be enriched during pure sediment mobilization or after deposition. Given the immobile nature of riparian soils, heavy metals enrichment in the riparian soils must be ascribed to metal adsorption from soluble fractions or vertical transfer from overlaid sediments. The lateral decreasing tend of the contents of heavy metals may also be explained by the occurrence of different flooding durations at different elevations of the riparian zone.

Acknowledgements This study was jointly funded by the Chinese Academy of Sciences (Grant KZCX2-XB3-09) and the National Natural Science Foundation of China (Grant 41171222, 41201272).

\section{REFERENCES}

Allen, S.E. (1989) Chemical Analysis of Ecological Materials. Oxford, UK: Blackwell.

Fu, B.J., et al. (2010) Three Gorges Project: efforts and challenges for the environment. Progress in Physical Geography 6, $741-754$.

He, X.B., et al. (2009) Tillage pedogenesis of purple soils in southwestern China. Journal of Mountain Science 6, 205-210.

Li, K.F., et al. (2013) Problems caused by the Three Gorges Dam construction in the Yangtze River basin: a review. Environmental Reviews 3, 127-135.

Lin JJ, Fu C, Zhang XD, Xie K \& Yu ZG. (2012) Heavy Metal Contamination in the Water-Level Fluctuating Zone of the Yangtze River within Wanzhou Section, China. Biological Trace Element Research 2, 268-272.

Song, Y.X., et al. (2010) Heavy metal contamination in suspended solid of Changjiang River: environmental implications. Geoderma 159, 286-295.

Tang, J., Zhong, Y.P. and Wang, L. (2008) Background value of soil heavy metal in the Three Gorges Reservoir District. Chinese Journal of Eco-Agriculture16, 848-852 (in Chinese with English abstract).

Tang, Q., et al. (2014) Sedimentation and associated trace metal enrichment in the riparian zone of the Three Gorges Reservoir, China. Science of the Total Environment 479-480, 258-266.

Wang YC, Lei B \& Yang SM. (2012) Concentrations and pollution assessment of soil heavy metals at different water-level altitudes in the draw-down areas of the Three Gorges Reservoir. Environmental Science 33, 612-617 (in Chinese with English abstract). 
Xu, X.B., Tan, Y. and Yang, G.S. (2013) Environmental impact assessments of the Three Gorges Project in China: Issues and interventions. Earth-Science Reviews 124, 15 -125.

Ye, C., et al. (2012) Soil nitrogen dynamics following short-term revegetation in the water level fluctuation zone of the Three Gorges Reservoir, China. Ecological Engineering 38, 37-44.

Ye, C., et al. (2013) Assessing heavy metal pollution in the water level fluctuation zone of China's Three Gorges Reservoir using geochemical and soil microbial approaches. Environmental Monitoring and Assessment 1, 231-240.

Ye, C., et al. (2011) Assessing soil heavy metal pollution in the water-level-fluctuation zone of the Three Gorges Reservoir, China. Journal of Hazardous Materials 1-3, 366-372.

Zhang, Q.F. \& Luo, Z.P. (2011) The environmental changes and mitigation actions in the Three Gorges Reservoir region, China. Environmental Science and Policy 8, 1132-1138. 